\title{
International Initiatives To Eliminate Corruption: Has Bribery Declined?
}

Claire R. La Roche, (E-mail: claroche@longwood.edu), Longwood University Mary A. Flanigan, (E-mail:mflaniga@ longwood.edu), Longwood University

\begin{abstract}
Bribery discriminates against honest companies by creating a barrier to entry in the form of a competitive disadvantage. An important legal issue with significant implications is whether recent international anti-corruption laws have leveled the playing field for firms doing business abroad. One of the first laws proscribing illicit payments to foreign public officials is the Foreign Corrupt Practices Act (FCPA), initially enacted by the U.S. Congress in 1977. From its inception, the FCPA has been criticized for placing U.S. firms at a competitive disadvantage based on the fact that few countries outlawed bribery of foreign officials. In the past ten years, several international treaties have been ratified that seek to criminalize bribery and eliminate the tax deductibility of corrupt payments made to foreign public officials. This paper discusses anticorruption laws and their effectiveness in creating a transparent business environment that discourages bribery.
\end{abstract}

\section{Introduction}

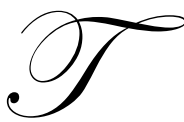

wenty-five years ago, bribery and corruption in association with international trade was prevalent, and to a certain extent, widely tolerated. Corruption in international trade was brought to the attention of the American public as a result of the Watergate investigation. The Office of the Special Prosecutor uncovered the existence of secret corporate "slush funds" commonly used by U.S. corporations to bribe foreign officials. These illicit payments ranged from minimal "grease payments" to government employees to ensure performance of ministerial duties, to substantial payments of bribes to government officials to obtain contracts (Sheffet, p. 290). In an effort to determine the extent to which these "slush funds" were being utilized, the Securities Exchange Commission initiated a voluntary disclosure program encouraging companies to conduct inhouse investigations of questionable activities. In a report to Congress, the SEC indicated that over 200 companies admitted making questionable foreign payments totaling over $\$ 300$ million. One of the most devastating facts to emerge from this investigation was the extent to which these companies were falsifying entries in their corporate books and records in an effort to conceal those payments (Cruver, p. 2). In response to increasing public sentiment against political corruption, the U.S. Congress enacted the Foreign Corrupt Practices Act (FCPA) in 1977. The FCPA is a sui generis law - that is a domestic criminal law applicable to acts committed outside the U.S. and was the first law prohibiting bribery in international transactions.

\section{Foreign Corrupt Practices Act}

The FCPA applies to firms under the jurisdiction of the Securities Exchange Commission. The anti-bribery provisions of the FCPA prohibit a company from giving, directly or indirectly through a third party, anything of value to a foreign official, political party, or political candidate, to obtain or retain business. In 1988, the Omnibus Trade and Competitiveness Act specifically excluded facilitating or "grease payments" made to a non-decisionmaking clerical or ministerial official from coverage under the FCPA. There are significant penalties for violating the FCPA. A person found guilty of violating this act may be fined up to $\$ 100,000$ and/or receive a five-year prison sentence. A corporation may be fined up to $\$ 2,000,000$ for violating the anti-bribery provisions (FCPA, $\$ 78 \mathrm{dd}-2(\mathrm{~g})$ ). In addition, the act includes provisions for potential commercial consequences including suspension or denial of an export license and loss of the privilege of doing business with the government. 
When the FCPA was passed in 1977, very few countries outlawed the payment of bribes to foreign officials. Furthermore, many countries permitted a tax deduction for corrupt payments made in connection with foreign trade. Consequently, there was little, if any, incentive within the business community to bring pressure to stop illicit payments. As markets in the world's transitional economies opened to foreign investment, the immature regulatory systems failed to provide the checks and balances necessary to control corruption. Consequently, these economies were fertile ground for corruption. After the FCPA was enacted, many businesses reported that they would have to forego some overseas business opportunities, particularly in emerging markets where corruption was rampant. Thus, the primary criticism of the FCPA is that it places U.S. businesses at a competitive disadvantage.

\section{Adverse Consequences of Bribery}

Like other white-collar crimes, many people assume that bribery is a victimless crime. This assumption could not be further from the truth. Bribery has negative consequences that present obstacles to social and economic development. For example, bribery places honest firms at a competitive disadvantage in the form of a barrier to entry. Thus, corruption may actually discourage competition or even lead to divestment. Another adverse consequence associated with bribery occurs when government officials are induced by bribery to enter into contracts. In this instance, corrupt payments may prevent the public from receiving optimal value for their money. Bribery also has the potential to lead to diversion of public funds to enrich individuals. For example, when organizations such as the World Bank invest capital in public works projects, corruption and bribery may lead to contracts being awarded to inefficient or even incompetent firms at inflated cost. Tolerance of corruption helps to undermine the judicial system and good governance in general and impedes economic prosperity.

\section{International Efforts to Eliminate Bribery and Corruption}

Corrupt business practices are not confined to just a few countries. In an effort to level the playing field, the United States has exerted diplomatic pressure on its international trading partners to outlaw bribery of foreign officials and politicians. At times, the United States has been criticized for acting as a moral imperialist by trying to impose American cultural standards to actions that occur in other societies. However, in an increasingly global economy, most countries have come to the realization that there is no logical justification for the discrepancy in treatment between bribing foreign officials and domestic officials.

Significant steps have been taken by supranational organizations including the Organization of American States, the Organization for Economic Cooperation and Development, the United Nations, and the World Bank in an attempt to legislate moral business conduct abroad. The Inter-American Convention Against Corruption (IACAC) was the first regional anti-corruption treaty. The Organization of American States (OAS) adopted the IACAC in 1996. The OAS recognized that bribery and corruption not only undermine democracy, but also have significant economic and social costs that are difficult to measure. According to the OAS, the primary goal of this treaty was to strengthen cooperation among member nations in an effort to fight corruption in the hemisphere. The IACAC signatory countries agreed to specific preventative and remedial measures to eliminate corruption and have implemented a means to monitor compliance with key provisions. Each country is to report the level of progress in developing a legal framework for implementing the IACAC and evaluate its adequacy. This report to the OAS also addresses to what extent results have been generated.

In December 1997, ministers of the thirty countries comprising the Organization for Economic Cooperation and Development, along with five other countries (Argentina, Brazil, Bulgaria, Chile, and Slovakia), signed the Convention on Combating Bribery of Foreign Public Officials in International Business Transactions (OECD Convention). This convention went into effect on February 15, 1999, and its provisions criminalize bribery and seek to eliminate tax deductions for corrupt payments made to foreign public officials. In part it provides that the signatory countries will take necessary steps to establish criminal laws prohibiting

"any person intentionally to offer, promise or give any undue pecuniary or other advantage, whether directly or through intermediaries, to a foreign public official, for that official or a third party, in order that the official act or 
refrain from acting in relation to the performance of official duties, in order to obtain or retain business or other improper advantage in the conduct of international business." (OECD Convention, Article 1)

As of December 13, 2002, all thirty OECD countries and four of the five other countries (excluding Slovakia) had ratified the convention. In an effort to support the OECD anti-bribery convention, the International Chamber of Commerce (ICC) adopted Rules of Conduct with which it asks its members to comply. These Rules of Conduct prohibit the demand or payment of a bribe and require transparency in accounting.

On October 31, 2003, The U.N. General Assembly adopted the first truly global response to anticorruption, the United Nations Convention Against Corruption (UNCAG). The UNCAG contains measures aimed at preventing corruption and establishes a comprehensive set of guidelines for all countries to follow. The primary provisions of this convention provide for international monitoring, public and private sector transparency in accounting, cooperative prosecution, and criminalizing corrupt activities such as bribery, trading in influence, and the "laundering" the proceeds of illegal activities.

The World Bank has also taken a stand against corruption. In 1997, the World Bank adopted a comprehensive strategy aimed at preventing corruption associated with projects it finances. As part of their anticorruption strategy, the World Bank also agreed to help countries around the world fight corruption and to support international efforts to eliminate corruption.

\section{Bribe Payers Index (BPI)}

Transparency International (TI) is a unique international organization dedicated to reducing corruption. In an effort to create tools to measure corruption, TI established the Bribe Payer's Index (BPI) in 1999. A second survey was completed in 2002. The BPI is based on Gallup surveys conducted in fifteen emerging market countries (Argentina, Brazil, Colombia, Hungary, Indonesia, Mexico, Morocco, Nigeria, the Philippines, Poland, Russia, South Africa, South Korea, and Thailand). The survey questions relate to the propensity of twenty-one countries to bribe high-level public officials in connection with obtaining and retaining international business. The BPI uses the results from these surveys to measure an exporting country's propensity to bribe while conducting business abroad. The following charts illustrate the results of these surveys. The higher the score, the lower the perceived propensity to bribe. Thus, the best possible score is 10 . It should be noted that the average BPI for the respondent countries was 1.9 , indicating a culture where it was perceived that a significant level of corruption existed.

Comparing the results of the 1999 BPI poll to the 2002 BPI poll, the mean for all countries included in the BPI increased from 5.931 to 5.985. This improvement in the BPI mean may be due in part to increased international attention being placed on anti-corruption efforts. At the time the 2002 BPI survey was conducted, the OECD Convention was the most comprehensive international anti-corruption initiative. According to Transparency International, most of the countries included in the 2002 survey had ratified the OECD Convention as of May 14, 2002, with the exception of Singapore, Malaysia, Hong Kong, China, and Russia.

The chart below compares 1999 and 2002 mean BPI scores for countries that had ratified the OECD Convention on Combating Bribery of Foreign Public Officials in International Business Transactions with those of the countries participating in the BPI poll that had not signed the OECD Convention as of May 14, 2002.

The mean score for the countries that had not ratified the OECD Convention prior to the 2002 BPI survey was 4.233 while the mean score for the countries that had already ratified the OECD Convention was 6.686. Thus, the 2002 poll indicated that countries that had ratified the OECD Convention were approximately $37 \%$ less likely to engage in bribery than non-signatory countries. When comparing the results of the 1999 BPI to the 2002 BPI, the mean score for the non-signatory countries of Singapore, Malaysia, Taiwan, and China increased from 4.05 to 4.233, indicating that their propensity to bribe had declined. Russia and Hong Kong were not included in this calculation because they were not part of the 1999 BPI. 

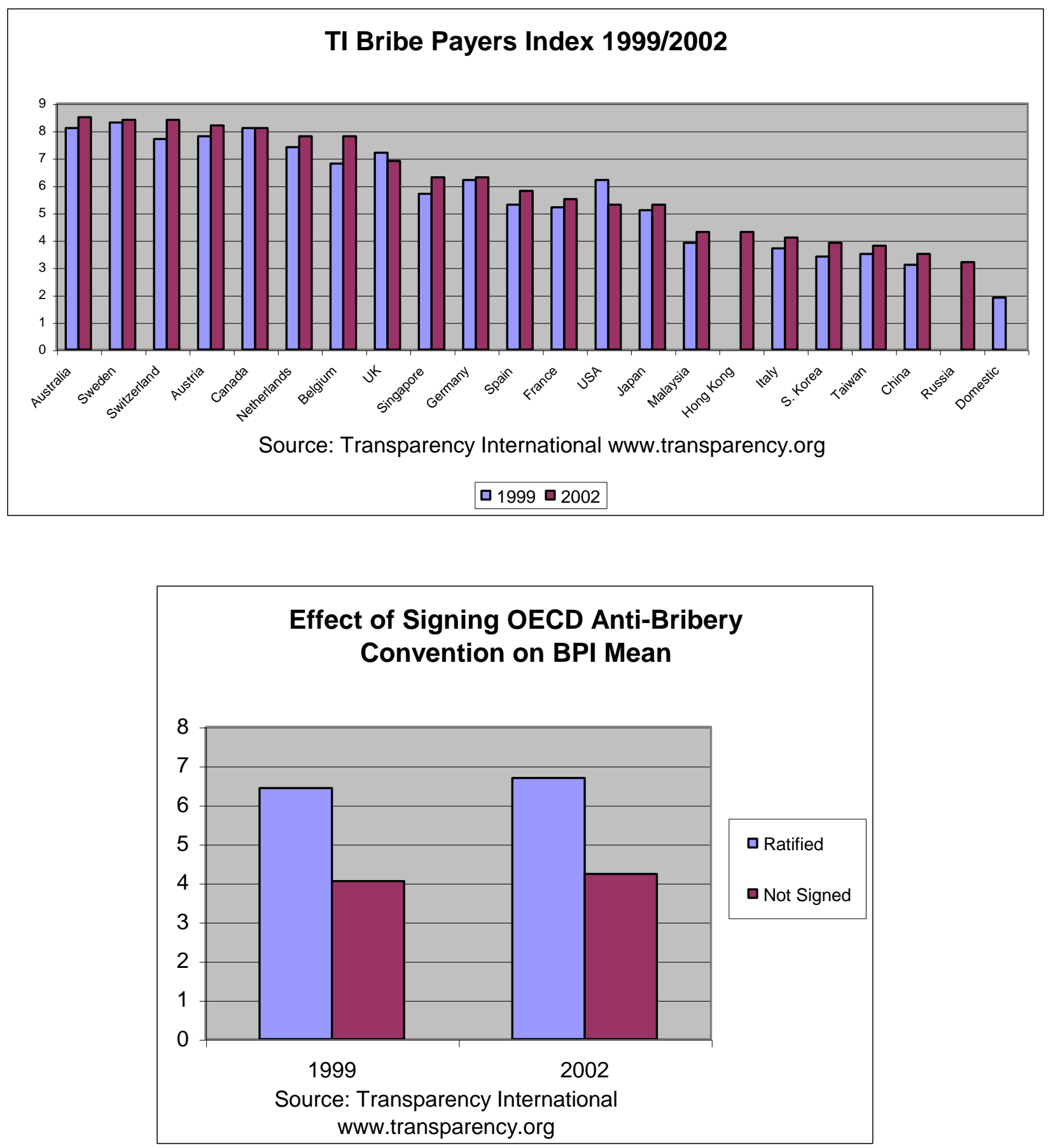

The mean BPI score of the 15 countries that had ratified the OECD Convention increased from 6.433 in 1999 to 6.686 in 2002. One inference is that countries that had ratified the Convention may be more cognizant of the adverse effects of bribery. Twelve of these countries increased their BPI score in 2002 and Canada's remained unchanged. The score for the United Kingdom and the United States decreased, a sign that the perceived propensity to bribe actually increased in these two countries from 1999 to 2002. 


\section{Conclusion}

Corruption is a complex and pervasive international problem that has found its place on the world's agenda. In the past ten years, significant steps have been taken by both individual governments and supranational organizations to combat bribery. Overall, the BPI indicates that perceived bribery associated with international business transactions decreased slightly from 1999 to 2002. While this is encouraging news, it is difficult to ascertain whether firms doing business abroad have become more ethical or simply more cautious. Without significant means of enforcement for international treaties and regulations, these attempts to reduce bribery of foreign officials may fail to deter illicit acts. Unfortunately, one can prescribe morality through legislation but acceptance of the moral tenet is an individual decision.

\section{References}

1. Cruver, Donald R., Complying With the Foreign Corrupt Practices Act. $1^{\text {st }}$ Edition, Chicago: American Bar Association, 1994.

2. Foreign Corrupt Practices Act, USC Title 15. Commerce and Trade Chapter 2B - Securities Exchanges.

3. Inter-American Convention Against Corruption, www.oas.org/juridico/english/Treaties/b-58.html (accessed 1/23/04)

4. OECD Convention on Combating Bribery of Foreign Public Officials in International Business Transactions, www.tcc.mac.doc.gov (accessed 1/20/04).

5. Sheffet, Mary Jane, (1995) "The Foreign Corrupt Practices Act and the Omnibus Trade and Competitiveness Act of

6. $\quad$ 1988: Did They Change Corporate Behavior?", Journal of Public Policy and Marketing, 14(2).

7. Transparency International Bribe Payers Index, http://www.transparency.org/cpi/2002/bpi2002.en.html, accessed 1/20/2004. 
Notes 